\title{
The impact of investor sentiment for the U.S. stock market based on Fama-French 3-factor model
}

\author{
Sifan $\mathrm{Yu}^{1, *}$ \\ ${ }^{1}$ HR Department, Bank of Shanghai Nanjing Branch, Nanjing, Jiangsu, 210000, China
}

\begin{abstract}
Particularly, it is difficult to accurately measure investor sentiment due to the inherent complexity and dynamic change. This paper tests the impact of investors' behavior in the U.S. equity market. By using monthly data from February 2014 to December 2018, the impacts of investor sentiment are examined. Besides, Fama-French risk factors are investigated in a new multiple factor asset pricing model. Specifically, the investor sentiment is measured by six-variable composite index. Empirical results indicate that the investor sentiment is a composition of systemic risk. In this case, the Fama-French three factor model with investor sentiment factor can fully explains the return of stocks in the USA stock market. By comparing the trend of investor sentiment and market index, investor sentiment will affect asset pricing and market volatility, i.e., verifies the effectiveness of investor sentiment index in the U.S, stock market.
\end{abstract}

\section{INTRODUCTION}

The research of capital market, especially the capital asset pricing, has been one of the hot spots in modern financial field. The capital asset pricing model predicts the relationship between asset risk and expected return, which is regarded as the benchmark of modern financial economics [1].

Classical financial theory assumes that the behavior of investors follows the expected utility maximization and The Bayesian law, which ignores the impact of investor sentiment on asset pricing. Behavioral finance theory treats human beings as bounded rational. The existence of the cognitive bias and preference of investors turns into a priced risk, which distorts the asset prices [2]. Based on the noise trader model proposed by Fischer Black [3], DeLong, Shleifer, Summers and Waldmann [4] developed the DSSW model, which takes investor sentiment as an important determinant of stock price for the first time. Depending on the circumstances, irrational investment behaviors (e.g., herd effect and overreaction) generally exist in the capital market. Investor sentiment not only affects investors' decisionmaking behaviors, but also contributes to the irrational exuberance and panic decline of the stock market in financial bubbles and crisis. [5] However, they only consider the impact of investor sentiment, which could not fully explain the variation of stock returns [6].

In this paper, the impact of investor sentiment will be verified for the U.S. stock market. In addition to the investor sentiment index, the situation of company has a significant impact on the expected return of the portfolio. Therefore, the value factor and size factor are introduced into the model to check investor sentiment behaviors on the portfolio classified by different size and book-tomarket ratio.

The remainder of this study is organized as follows: the related literatures are reviewed in Sec. 2; Sec. 3 describes the data and explains our research methodology; test results are analyzed in section 4, followed by the possible implications of the findings; a brief summary is given in Sec. 6 eventually.

\section{LITERATURE REVIEW}

Markowitz [7] proposes the Mean-Variance model for portfolio investment and proves the positive correlation between risk and return. It is the first time that mean and variance of portfolio returns are used to define investor's preference mathematically. On this basis, Sharpe[1] suggests the Capital Asset Pricing Model (CAPM), which measures the risk and help investors judge whether the additional return matches the risk. Afterwards, CAPM Model has become the benchmarks of modern financial economics, which predicts the relationship between portfolio returns and market returns and evaluates the performances of the price equilibrium. However, the CAPM model has limitations. It is too simple to account for the differences between individual firms [8]. Some researchers try to make some extensions on CAPM. For instance, Fama and French [9] add size and value factors into the CAMP model and conduct empirical research on the U.S. stock market. They prove that the beta value of stock market does not fully account for the difference in stock returns. By introducing the value risk (HML) and the size risk (SMB), Fama-French 3 -factor model can measure the excess return on the market better. Since then, their findings have received a

\footnotetext{
* Corresponding author: yusf@bosc.cn
} 
lot of support, i.e., the robustness of the Fama-French model has been checked [10].

However, some researchers have questioned the Fama-French model. Campbell [11] proves that the coefficient of relative risk aversion is much higher than the price of stock market risk in the presence of human capital ad investor sentiment. Carhart [12] investigates the role of the momentum trading in the stock return. Lam [13] demonstrates the effect of liquidity on the stock return in the Hong Kong stock market.

Over the past three decades, scholars have recognized that behavioral factors including investor sentiment have impacts on asset pricing [14]. The behavioral theory proposed by DeLong, Shleifer, Summers and Waldmann [4] believes that noise trader sentiments exist in the financial market. According to their theory, assets which exposed to noise trader are riskier, i.e., require additional return. The propositions put forward by Lee, Shleifer, and Thaler [15] proves that the fluctuations of individual investor sentiment lead to the change in discounts of closed-end funds. Qiu and Welch [16] measure investors sentiment by using consumer confidence surveys and examine that investors sentiment persists in financial markets, comparing with the way of measuring extracted from the closed-end fund discount. By analyzing the expectation of investor sentiment on various information in the market, Frankfurter and McGoun [17] explain the anomaly of stock premium that could not be explained in the traditional asset pricing theory. Ljungqvist's [18] model relates the empirical IPO anomalies to investor sentiment. Baker and Wurgler [19] propose a "bottom up" approach by using biases in individual investor psychology to measure investor sentiment and quantify its empirical effects. By studying the effects of investor sentiment index in various countries' stock market, they find that the indexes are negatively correlated with their corresponding stock market indexes. Capital flows in developed countries result in a certain correlation between investor sentiment in different countries.

\section{MODEL AND METHODOLOGY}

\subsection{Data section}

The risk-free rate $\left(R_{f}\right)$ in this article is derived from the yield of the U.S.'s 13 Week Treasury, and the data is from Yahoo Finance Website [20]. The monthly yield of individual stocks $\left(\mathrm{R}_{\mathrm{it}}\right)$ uses the data calculating by the closing price of the 2,048 listed companies' stocks in the U.S. from February 2014 to December 2018. The data above obtains from the Wind database. The average of changes in the three major U.S. stock indexes (The Dow, the S\&P 500 and the Nasdaq) is used as the market index $\left(\mathrm{R}_{\mathrm{mt}}\right)$. The Book-to-market ratio is defined as the value risk factor (HML), which is obtained by dividing the shareholders' equity by the market value at the end of the period. The size risk factor (SMB) is defined as the size of the company achieved by multiplying the amount of stock issued by the closing price at the end of the month .
Since a single investor sentiment index is difficult to describe the whole capital market in a comprehensive way. Existing studies have proved that the single index usually has a certain timeliness. Composite investor sentiment index (INV) is constituted by multiple single indexes, which contain more information with stronger effectiveness. Thus, composite investor sentiment index is chosen, which constructed by six single indicators in this paper (Closed-end fund discount, Average first-day return, Number of IPOs, New accounts, Turnover and Consumer Confidence Index). The use of principal component analysis weakens the interference of nonemotional factors on the investor sentiment index.

\subsection{Methodology}

To test the hypothesis that investor sentiment plays a significant role in the portfolio returns, investor sentiment factor is added into Fama-French three-factor model as:

$$
E\left(R_{i t}\right)-R_{f}=\beta_{i}\left(E\left(R_{m t}\right)-R_{f}\right)+\alpha_{i} S M B_{p / t}+b_{i} H M L_{p / t}+c i I N V_{t}
$$

According to the grouping criteria of Fama-French three-factor model, the market value at the end of each year is used to sort 2048 stocks into two groups: large market value (B) and small market value (S) $(50 \%$ and $50 \%$ ). The book-to-market ratio is used to separate 2048 stocks into 3 groups: high book-to-market ratio $(\mathrm{H})$, medium book-to-market ratio (M) and low book-tomarket ratio (L) $(30 \%, 40 \%$ and $30 \%)$. In this case, the ordinary data are divided into 6 groups.

The weight of each group is obtained by dividing the year-end market value of an individual stock by the total market value of the whole group at the end of the year:

$$
W_{i}=C A P_{i} / \sum n i=1 C A P_{i}
$$

$\mathrm{CAP}_{\mathrm{i}}$ is the year-end market value of the stock $i$, and the weighted portfolio monthly return rate is calculated by using the weights obtained above: $E\left(R_{i t}\right)=\sum n i=1 W_{i} R_{i t}$. Then, the size risk factor (SMB) and the value risk factor (HML) are calculated by using the weighted portfolio monthly return rate with the forms:

$$
\begin{gathered}
S M B=(S / L+S / M+S / H) / 3-(B / L+B / M+B / H) / 3 \\
H M L=(S / H+B / H) / 2-(S / L+B / L) / 2
\end{gathered}
$$

Table 1. Statistics descriptions of the monthly yield of 6 different groups divided by using the grouping criteria of Fama-French three-factor model

\begin{tabular}{cccccc}
\hline Variable & Obs & Mean & Std. Dev. & Min & Max \\
\hline S/L & 59 & $4.14 \mathrm{E}-05$ & 0.000256 & -0.00062 & 0.000425 \\
S/M & 59 & $1.84 \mathrm{E}-06$ & 0.000114 & -0.00032 & 0.000286 \\
S/H & 59 & $-2.3 \mathrm{E}-05$ & 0.000124 & -0.00038 & 0.000296 \\
B/H & 59 & $-1.74 \mathrm{E}-06$ & 0.000188 & -0.00053 & 0.000389 \\
B/M & 59 & $2.96 \mathrm{E}-06$ & $7.34 \mathrm{E}-05$ & -0.00025 & 0.000171 \\
B/L & 59 & 0.000321 & 0.020569 & -0.08551 & 0.068883 \\
\hline
\end{tabular}


As listed in Table 1, the mean of the $\mathrm{S} / \mathrm{H}$ and $\mathrm{B} / \mathrm{H}$ group are negative and lower than the other 4 groups. Therefore, it implies that the firm with high book-tomarket ratio is less profitable and easier to fall into financial crisis. The standard deviation of the $\mathrm{B} / \mathrm{L}$ group is higher than the other five groups, indicating that the firm with larger size and lower book-to-market ratio has higher fluctuation.

\section{EMPIRICAL APPLICATION}

In this paper, investor sentiment index is used alone to explain the returns in the U.S. stock market at first. The regression results of the investor sentiment index are summarized in Table 2.

Table 2. Regression results of the investor sentiment index.

Ri-Rf Coef. Std. Err. $\quad$ t P>|t $\mid \mathbf{9 5 \%}$ Conf. Interval] Adj. $\mathbf{R}^{2}$

INV $0.1043640 .0401012 .6 \quad 0.0120 .024062 \quad 0.184665$

0.1062

Cons. 0.0172810 .0059742 .890 .0050 .0053190 .0292436

Notes: This table reports coefficients, $\mathrm{p}$-value and adjusted $\mathrm{R}^{2}$ of investor sentiment index, estimated in time series regressions for the U.S. stock market.

The results reveal that the coefficient of investor sentiment index is positive. Besides, investor sentiment can have a significant impact on the return of the U.S. stock market, indicating the validity of investor sentiment index constructed in this paper. However, the adjusted R2 is 0.106 and the goodness of fit of the model is low, suggesting that the explanatory power of investor sentiment alone for stock market returns is insufficient. Thus, we add investor sentiment factor in the FamaFrench three-factor model, and perform regression analysis on 6 groups mentioned.

According to the results shown in Table. 3, all the adjusted $\mathrm{R}^{2}$ are larger than 0.5 which means the goodness of fit is high, indicating that the explanatory power of this model is more sufficient,. All groups pass the F-test, which implies the model is significant, i.e., Market factor (MKT), size factor (SMB), value factor (HML) and investor sentiment factor (INV) together can explain the changes of the group's excess return well.

The coefficient of investor sentiment index is larger in the small-cap stocks than that in the large-cap stocks. As a consequence, it denotes that small-cap stocks are more sensitive to the investor sentiment. Hence, one can conclude that small-cap stocks have poor liquidity in the stock market and are more vulnerable to shocks. In other words, the price of small-cap stocks is more sensitive to the trading behavior of investors when investor sentiment fluctuates.

In portfolio $\mathrm{B} / \mathrm{L}, \mathrm{P}$-value of market factor and investor sentiment factor is larger than 0.05 . On this occasion, under $5 \%$ significance level, it is unable to reject the null hypothesis and conclude that the market factor and investor sentiment factor are not significant in group $\mathrm{B} / \mathrm{L}$. This type of enterprises usually has a good capital structure, small price bubble, and low probability of decline and raise. The value of such enterprises is stable and will not change greatly due to the trading of investors. Therefore, investor sentiment has little influence on such enterprises.

Table 3. Regression results of the investor sentiment based on Fama-French three-factor model.

\begin{tabular}{|c|c|c|c|c|c|c|c|c|c|}
\hline \multirow{2}{*}{ group } & \multirow{2}{*}{ intercept } & MKT & SMB & HML & INV & \multirow{2}{*}{$\begin{array}{c}F \\
\text { F-test }\end{array}$} & $\mathrm{P}$ & \multirow{2}{*}{\multicolumn{2}{|c|}{$\frac{\mathrm{R}^{2} \quad \text { Adj-R2 }}{\text { Goodness of fit }}$}} \\
\hline & & \multicolumn{4}{|c|}{ Regression Results } & & & & \\
\hline \multirow{3}{*}{$\mathrm{S} / \mathrm{L}$} & -0.0005 & 0.0111 & 2.2049 & -1.466 & 0.0013 & & & & \\
\hline & $(t=-11.79$ & $(t=6.04$ & $(t=14.21$ & $(t=-14.14$ & $(t=4.03$ & 73.16 & 0 & 0.8442 & 0.8327 \\
\hline & $\mathrm{p}=0)$ & $\mathrm{p}=0)$ & $\mathrm{p}=0)$ & $\mathrm{p}=0)$ & $\mathrm{p}=0)$ & & & & \\
\hline \multirow{3}{*}{$\mathrm{S} / \mathrm{M}$} & -0.0006 & 0.0079 & 2.0008 & -1.327 & 0.0011 & & & & \\
\hline & $(t=-9.50$ & $(\mathrm{t}=3.31$ & $(t=9.95$ & $(t=-9.88$ & $(t=2.75$ & 32.84 & 0 & 0.7087 & 0.6871 \\
\hline & $\mathrm{p}=0)$ & $\mathrm{p}=0.002)$ & $\mathrm{p}=0)$ & $\mathrm{p}=0)$ & $\mathrm{p}=0.008)$ & & & & \\
\hline \multirow{3}{*}{$\mathrm{S} / \mathrm{H}$} & -0.0006 & 0.0082 & 2.0035 & -1.3288 & 0.0012 & & & & \\
\hline & $(\mathrm{t}=-9.78$ & $(t=3.4$ & $(\mathrm{t}=9.85$ & $(\mathrm{t}=-9.78$ & $(\mathrm{t}=2.82$ & 32.59 & 0 & 0.7071 & 0.6854 \\
\hline & $\mathrm{p}=0)$ & $\mathrm{p}=0.001)$ & $\mathrm{p}=0)$ & $\mathrm{p}=0)$ & $\mathrm{p}=0.007)$ & & & & \\
\hline \multirow{3}{*}{$\mathrm{B} / \mathrm{L}$} & -0.0008 & 0.004 & 5.8155 & -5.8637 & 0.0001 & & & & \\
\hline & $(\mathrm{t}=-4.08$ & $(\mathrm{t}=0.51$ & $(\mathrm{t}=8.78$ & $(\mathrm{t}=-13.25$ & $(\mathrm{t}=0.06$ & 4200.38 & 0 & 0.9968 & 0.9966 \\
\hline & $\mathrm{p}=0)$ & $\mathrm{p}=0.615)$ & $\mathrm{p}=0)$ & $\mathrm{p}=0)$ & $\mathrm{p}=0.953)$ & & & & \\
\hline \multirow{3}{*}{$\mathrm{B} / \mathrm{M}$} & -0.0006 & 0.0074 & 1.8599 & -1.2328 & 0.0011 & & & & \\
\hline & $(\mathrm{t}=-8.61$ & $(\mathrm{t}=2.83$ & $(\mathrm{t}=8.48$ & $(\mathrm{t}=-8.41$ & $(\mathrm{t}=2.46$ & 23.98 & 0 & 0.6398 & 0.6131 \\
\hline & $\mathrm{p}=0)$ & $\mathrm{p}=0.007)$ & $\mathrm{p}=0)$ & $\mathrm{p}=0)$ & $\mathrm{p}=0.017)$ & & & & \\
\hline \multirow{3}{*}{$\mathrm{B} / \mathrm{H}$} & -0.0006 & 0.0105 & 1.8236 & -1.2107 & 0.0011 & & & & \\
\hline & $(\mathrm{t}=-8.32$ & $(\mathrm{t}=3.71$ & $(\mathrm{t}=7.66$ & $(\mathrm{t}=-7.61$ & $(\mathrm{t}=2.2$ & 22.18 & 0 & 0.6216 & 0.5936 \\
\hline & $p=0)$ & $\mathrm{p}=0)$ & $\mathrm{p}=0)$ & $\mathrm{p}=0)$ & $\mathrm{p}=0.032)$ & & & & \\
\hline
\end{tabular}

Notes: This table reports coefficients, p-value and adjusted $\mathrm{R}^{2}$ of risk factors in six different groups, estimated in time series regressions for the U.S. stock market. 


\section{CONCLUSION}

In summary, the impact of investor sentiment is investigated based on Fama-French 3-factor model for the U.S. stock market. In order to conduct the investor sentiment index, lots of timeseries are obtained by principal components analysis based on the monthly data from February 2014 to December 2018 (e.g., closed-end fund discount, average first-day return, number of IPOs, new accounts, turnover and consumer confidence index). The results perform that investor sentiment index has a high correlation with the return of stocks. However, the explanatory degree of the stock market is low when the investor sentiment is used alone. Subsequently, the investor sentiment index is added into the Fama-French 3-factor model to analyze the impact of investor sentiment on stock returns. The result proves that this model can explain the stock returns better. Moreover, the impact of investor sentiment on small-cap stocks is more sensitive. Nevertheless, the feasible path to avoid the volatility caused by investor sentiment hasn't been discussed here, which will be one of the future topics. These results offer a guideline for investors to reduce the risk.

\section{References}

1. William F, The R . SHARPE. Capital Asset Prices: of Market Equilibrium under Conditions of of Finance[J]. Journal of Cell Biology, 1964, 98(2):407-16.

2. Gunathilaka C, Jais M . Investor Sentiment, Human Capital and Fama French Factors: Measurement and Performance in the Malaysian Market[J]. Jurnal Pengurusan, 2019, 55(19):135-146.

3. Fischer B . Noise[J]. Journal of Finance, 1986, 41(3):529-543.

4. Long J , Shleifer A, Waldmann S . Noise traders and risk in financial markets[J]. Journal of Political Economy, 1990, 98(4):703-738.

5. Brown G W . Volatility, Sentiment, and Noise Traders[J]. Financial Analysts Journal, 1999, 55(2):82-90.

6. GW Brown, MT Cliff. Corrigendum to "Investor sentiment and the near-term stock market" [J. Empirical Finance 11 (2004) 1 - 27][J]. journal of empirical finance, 2004, 11(4):0-628.

7. Markowitz H M . Portfolio selection[J]. The Journal of Finance, 1952, 7(1):77.

8. Qadan M, Aharon D Y . Can investor sentiment predict the size premium?[J]. International Review of Financial Analysis, 2019, 63(MAY):10-26.

9. Fama E F , French K R . Common risk factors in the returns on stocks and bonds[J]. Journal of Financial Economics, 1993, 33(1):3-56.

10. Mustafa, Sayim, Hamid, et al. The relationship between individual investor sentiment, stock return and volatility[J]. International Journal of Emerging Markets, 2015.

11. Campbell J Y . Understanding Risk and Return[J]. Journal of Political Economy, 1996, 104(2): 298345.

12. Carhart M M . On Persistence in Mutual Fund Performance[J]. Social Science Electronic Publishing, 1997, 52(1):57-82.

13. Lam K , Tarn L H K . Liquidity and asset pricing: Evidence from the Hong Kong stock market[J]. Journal of Banking \& Finance, 2011, 35(9):22172230.

14. Stein J C . Rational Capital Budgeting in an Irrational World[J]. Scholarly Articles, 1996.

15. Lee C, Shleifer A, Thaler R H . Investor Sentiment and the Closed - End Fund Puzzle[J]. The Journal of Finance, 1991, 46(1):75-109.

16. Qiu L X, Welch I . Investor Sentiment Measures[J]. Nber Working Papers, 2004, 117(35):367-377.

17. Frankfurter G M , Mcgoun E G. Anomalies in finance: What are they and what are they good for? [J]. International Review of Financial Analysis, 2001, 10(4):407-429.

18. Ljungqvist A , Nanda V , Singh R . Hot Markets, Investor Sentiment, and IPO Pricing[J]. The Journal of Business, 2006, 79(4):1667-1702.

19. Baker M, Wurgler J . Investor Sentiment in the Stock Market[J]. Journal of Economic Perspectives, 2007, 21(2):129-152.

20. Information from http://www.finance.yahoo.com/ 